\title{
PSYCHE
}

VOL. XXXIII.

AUGUST-OCTOBER

Nos. 4-5

\section{SOME NEW NEOTROPICAL ANTS}

By W. M. ManN

U. S. National Museum, Washington, D. C.

Descriptions of the new species given in the following paper are presented at this time so their names may be used in connection with new species of myrmecophilous beetles. One interesting new form, which has been collected from the stomach of a toad by members of the Bureau of Biological Survey, is also included.

\section{Eciton gracellæ, new species.}

Worker.-Length 2.75-4 mm.

Head a little longer than broad, broadest in front of middle, sides moderately convex, posterior corners narrowly rounded, border shallowly concave. Eyes very distinct, situated a little behind the middle of front of sides. Mandibular blades finely and bluntly denticulate. Antennal scapes extending a little beyond the eyes, all funicular joints longer than broad. Thorax rather slender, in profile evenly convex. Epinotum on a lower plane than the promesonotum, its surface shallowly impressed at basal half, very feebly convex behind, twice as long as broad and one and one half times as long as the declivity, into which it very broadly rounds. Petiole in profile a little longer than high, convex above, with the antero-ventral spine strong, elongate, curved and acute at apex, extending backward; from above longer than broad, with feebly convex sides, postpetiole in profile as long as high and convex above; from above a little longer than broad, with nearly straight sides. Legs long, rather slender, claws simple. 
Shining. Mandibles rather coarsely striate. Head and body sparsely, moderately, coarsely punctate, except on the impressed anterior portion of epinotum and on the meso- and metapleuræ which are densely punctate and subopaque.

Fine, elongate, erect yellowish hairs abundant on head, body and appendages, on the gaster mixed with shorter and subappressed hairs.

Gaster dark brown to black, remainder bright brownish red.

Type locality.-Ototonilco, Jalisco, Mexico.

Cotypes.-Cat. No. 29045 U. S. N. M.

Described from nine workers taken from a file running through the grass in an orange grove, and named in honor of Señorita Graciella Mercedes Maderiaga, the child who found them.

Eciton (Acamatus) peninsulare, new species.

Worker major. Length $3.5 \mathrm{~mm}$.

Head about one fifth longer than broad, slightly broader in front than behind, with broadly and shallowly concave posterior border and rounded corners. Eyes not discernible. Mandibles with several rather stout, separated teeth basally and one larger one forming an angle between the base and the blades. Antenna stout, scape broadened and somewhat compressed apically, extending about three eighths the distance to occipital corners; funicular joints 2 to 8 a little broader than long, 9 and 10 as long as broad, apical about as long as the two preceding joints together. Thorax rather stout, compressed laterally, nearly flat above; epinotum more than half as long as pro- and mesothorax together, its base on the same plane as the mesonotum and separated from it by a narrow, though strong impression, declivity distinctly shorter than the base and broadly rounding into it. Petiole in profile only slightly longer than high, convex above, antero-ventral tooth moderate in size and blunt at tip; from above subquadrate, about ac long as broad; postpetiole from above transversely oval and one third broader than the petiole; antero-ventral tooth stout and blunt at tip. Claws simple. 
Shining. Mandibles with short, coarse striæ; head and body with distinct, widely separated punctures, coarsest and most abundant on the mesonotum, finest on the gaster.

Suberect, fine yellowish hairs rather sparsely distributed on head, body and appendages.

Color pale to rather dark brownish yellow.

Worker minor. Length $1.5 \mathrm{~mm}$.

The smallest specimens in the colony differ in having the head one and two thirds times as long as broad, with straight sides (convex in the larger workers) and more deeply excavated posterior border and the meso-epinotal impression feebly impressed.

Type locality.-La Palma Davila, Lower California.

Cotypes. Cat. No. 29046 U. S. N. M.

Described from a series of 33 workers taken by the writer from a cluster beneath a stone. Among them were numbers of a Staphylinid beetle, which I have recently described as Pulicomorpha coccum.

Eciton peninsulare is related to Eciton californicum Mayr, but much smaller in size and distinct in the absence of eyes, the more elongate head, as well as the smoother, more shining and sparsely punctate integument.

\section{Eciton (Acamatus) sumichrasti Norton.}

\section{Female.-Length $11.5 \mathrm{~mm}$.}

Head from the front about as long as broad, slightly broader in front than at occipital border, sides feebly rounded, occipital border emarginate, occiput and vertex with large impressed areas; vertex and front with a median longitudinal groove that becomes stronger anteriorly and terminates at posterior border of clypeus. Ocelli lacking; eyes of a single, white facet, situated a little behind middle of sides of head. Mandibles slender, thickest at middle, nearly straight, their tips obtusely pointed. Median, triangular portion of clypeus longer than broad, anterior border very feebly emarginate. Frontal carinæ anteriorly rather acute above, posteriorly broad and convex. Antennal scapes robust, clavate, about half as long as head; funiculi more 
slender than scape, the first joint as broad as long, the others distinctly longer than broad, the terminal slender, connate and nearly as long as the two preceding joints together. Thorax long, very gradually widened from front to rear, in profile about three times as long as deep, slightly rounded in region of pronotum, flat behind, the dorsal surface of mesonotum shallowly, though distinctly impressed at middle. Propleuræ shallowly and broadly impressed. Promesonotal suture very indistinctly indicated by an impressed line; mesometanotal suture not discernible. Meta-epinotal impression distinct. Basal portion of epinotum much longer than the flat declivity, into which it broadly rounds; dorsal surface a little broader than long, strongly and broadly impressed at middle, the impression deepest posteriorly, sides behind middle subgibbous. Petiole from above transverse, not as broad as epinotum, sides very feebly divergent behind, anterior corners broadly rounded, posterior corners projecting and obtusely angulate, posterior border strongly emarginate, dorsal surface concave at middle, with rather strong convexities at sides of concave portion, then sloping and indistinctly impressed toward lateral borders; seen from the side the node is much higher than long, arcuate in front and above and emarginate on posterior outline, with the anterior portion of sides convex and the posterior concave. Gaster elongate oval. Hypopygium and pygidium submembraneous at borders, which in the former are nearly straight and in the latter triangularly excised. Sting not visible. Legs rather short, slender. Claws simple.

Gaster shining, the rest nearly opaque. Head, thorax and epinotum densely and finely punctate, the head more shallowly than the rest, and in addition with scattered, coarser punctures most conspicuous on the epinotum. Petiole densely and shallowly punctate and more shining. Gaster with distinct, irregular, separated punctures, each of which bears a moderately long, stiff, finely pointed yellow recumbent hair. Mandibles and anterior border of clypeus sparsely punctate.

Erect hairs yellow, fine and abundant on head, thorax and petiole and appendages.

Dark ferrugineous red, appendages paler, antennæ yellowish. 
Described from a female found with a cluster of workers beneath a stone on the edge of the Barranca de Oblatos at Guadalajara, Jalisco, Mexico.

Alfaria bufonis, new species.

Worker.-Length $5 \mathrm{~mm}$.

Head one fourth longer than broad, as broad behind as in front, sides feebly convex, occipital corners broadly rounded, border shallowly concave. Clypeus slightly convex, broadly rounded at anterior border. Frontal area very distinct, the surface immediately in front strongly, transversely impressed. Antennal scapes slender basally, clavate toward apex, surpassing occipital corners by a distance nearly equal to their width at tip. Eyes small, round, convex, situated at middle of sides of head. Promesonotum widest in front of middle, sides very feebly rounded, surface slightly convex; inferior corners obtusely angulate. Epinotum separated from mesonotum by a distinct though narrow transverse groove, its basal surface on a lower plane than the mesonotum, as long as the declivity, broadened behind; slightly convex in profile. Petiolar node in profile longer than high, convex above, with a sloping anterior face; from above longer than broad, with sides rounded behind and nearly straight in front. Gaster similar to that of Alfaria simulans Emery.

Subopaque. Head, thorax and abdomen with coarse, irregular punctures, approximate and with the surface between appearing as a reticulum on the head and especially the pronotum, less approximate on dorsal surface of petiole and abdomen and widely separated on metapleuræ, the entire surface with a silk-like sheen; front of head at middle with a subtlely striate area; frontal lobes and mandibles rather coarsely striate; antennal scapes and legs with distinct, separated shallow punctures and dense microscopic striolæ.

Fine and silky, yellowish hairs moderately abundant on head, body and appendages.

Dark brown to black, with a red-brown tinge, mandibles and appendages lighter.

Type locality.-Choapam, Oaxaca, Mexico.

Type.-Cat. No. 29047 U. S. N. M. 
Described from a single worker taken from the stomach of a toad (Bufo valliceps Weig., U. S. N. M. 46967) collected by Nelson and Goldman, July 28, 1894.

The type lacks the antennal funiculi and portions of the legs, but is otherwise in good condition, with the pilosity well preserved. Alfaria simulans Emery, the nearest species, differs in its shorter and stouter antennal scapes, in the entire absence of an impression between meso- and epinotum, in its larger size and lighter color.

Leptogenys (Leptogenys) peninsularis, new species.

Worker.-Length $7.5 \mathrm{~mm}$.

Head, excluding mandibles, more than one and one half times as long as broad, a little broader in front than behind, with feebly arcuate sides, broadly rounded occipital corners and straight border. Clypeus carinate at middle, the anterior projecting triangular portion as broad as long and subacuminate at tip, the median lobes at middle of sides of front border low and rounded. Mandibles distinctly shorter than sides of head, seen from the front nearly straight, broadened apically, inner border of basal portion subcultrate and terminating in an inner small, broad lamellate triangle, blades strongly concave. Antennal scapes surpassing occipital angles by about three-eighths of their length, second funicular joint one and one-half times as long as the first, remaining joints shorter and slightly thicker toward apex, the terminal as long as the two preceding joints together. Eye about as long as its distance to border of clypeus. Pronotum as broad as long, broadest behind middle, sides convex, dorsal surface slightly convex. Mesonotum slightly longer than broad, with straight sides and posterior border. Meso-epinotal impression moderate. Epinotal base nearly straight in outline and about twice as long as the flat declivous portion, into which it broadly rounds. Petiolar node higher than long, anterior surface broadly convex, posterior surface flat, dorsum broadly rounding into anterior and narrowly into posterior surface; from above longer than broad, slightly widest behind, with sides feebly arcuate. Abdomen elongate; sting strong. Legs long and slender. 
Head and thorax subopaque, finely and densely reticulostriolate, the striæ transverse on posterior part of head, median portion of pronotum and on the meso-and epinotum; petiole with more subtle striation and gaster shining, with fine separated punctures. Mandibles sparsely and coarsely punctured and very finely striolate.

Fine, erect hairs rather sparse on head, body and legs; appressed yellow pilosity rather thin on head, thorax and abdomen.

Color ferrugineous.

Type locality.-Comondu, Baja California.

Cotypes.-Cat. No. 29048 U. S. N. M.

Described from 36 workers collected by the writer from colonies found beneath stones by the stream that waters the valley at Comondu. In size, structure of the head and mandibles and in sculpture and pilosity and coloration, Leptogenys peninsularis is widely different from any of the described neotropical species.

Erebomyrma nevermanni, new species.

Worker.-Length $1.25 \mathrm{~mm}$.

Head, excluding mandibles, a little longer than broad and about as broad in front as behind, with evenly arcuate sides, rounded occipital corners and very feebly concave border. Mandibular blades with four rather strong teeth. Median portion of clypeus convex, bordered at sides by narrow carinæ terminating at sides as triangular teeth, feebly emarginate at anterior border. Frontal carinæ delicate, continued to rear occipital border. Antennal scape extending slightly more than two-thirds the distance to occipital corners, slenderly clavate, first funicular joint stout, about as long as the three following together, joints 2-8 small, strongly transverse, club nearly as long as the remainder of funiculus, with the penultimate joint less than half as long as the terminal. Eyes minute, situated a little in front of middle of sides of head. Thorax robust. Pro-mesonotum feebly convex above, humeri subangulate, anterior border with a narrow elevated margin, sides feebly arcuate and converging to the posterior border which is a little more than half as broad as the anterior. 
Mesoëpinotal impression strong. Base of epinotum somewhat transverse, longer than the declivity and narrowly rounding into it; with a pair of acute triangular spines, nearly as long as their distance apart at base. Petiolar peduncle nearly as long as the node, which in profile is conical and as high as long, and from above elongate oval. Postpetiole longer than broad and twice as broad behind as in front, sides nearly straight, in profile much longer than broad, convex above. Femora slender basally and clavate apically; tibiæ stout.

Gaster and postpetiole, mandibles and legs shining, the remainder feebly shining. Mandibles sparsely punctate. Clypeus and middle of front smooth, remainder of head rugulose-punctate and with sparse striæ which are longitudinal on front, reticulate on occiput and diagonal on cheeks. Promesonotum sculptured like the head, with the striæ irregularly longitudinal. Epinotum and meta- and epipleuræ and petiolar peduncle cribrately punctate. Petiole, postpetiole, gaster and legs smooth.

Hairs long, erect and very fine, moderately abundant on thorax and abdomen, shorter and semirecumbent on head and appendages.

Rather pale reddish brown; legs, tip of antennæ and often the petiole and gaster yellowish.

Type locality.-Hamburg Farm, Reventazon, Santa Clara, Costa Rica.

Cotype.-Cat. No. 29049 U. S. N. M.

Mr. F. Nevermann found the colony in a rotten $\log$, in company with Euponera (Trachymesopus) stigma Fabr.

Erebomyrma longi Wheeler, from Texas, differs in having the head longer and, in profile, much thinner, the humeri are not angulate, the anterior border of pronotum, not margined, the epinotal spines shorter and the post petiole transverse, as well as in its finer sculpture and paler color.

Strumigenys (Tingimyrmex), new subgenus.

Head elongate, not strongly excised behind. Mandibles short, remote at base, with a series of microscopic teeth at apical third. Antennal scrobes deep and broad and extending length of 
head. Pronotal humeri with lamellate spines, postpetiole very large and broad. Clypeus, scrobes, posterior border of head, anterior border of thorax, sides of epinotum, upper and lower surfaces of petiole and lower surface of postpetiole with broad, thin, semitransparent lamellæ.

Genotype.-Strumigenys (Tingimyrmex) mirabilis, new species.

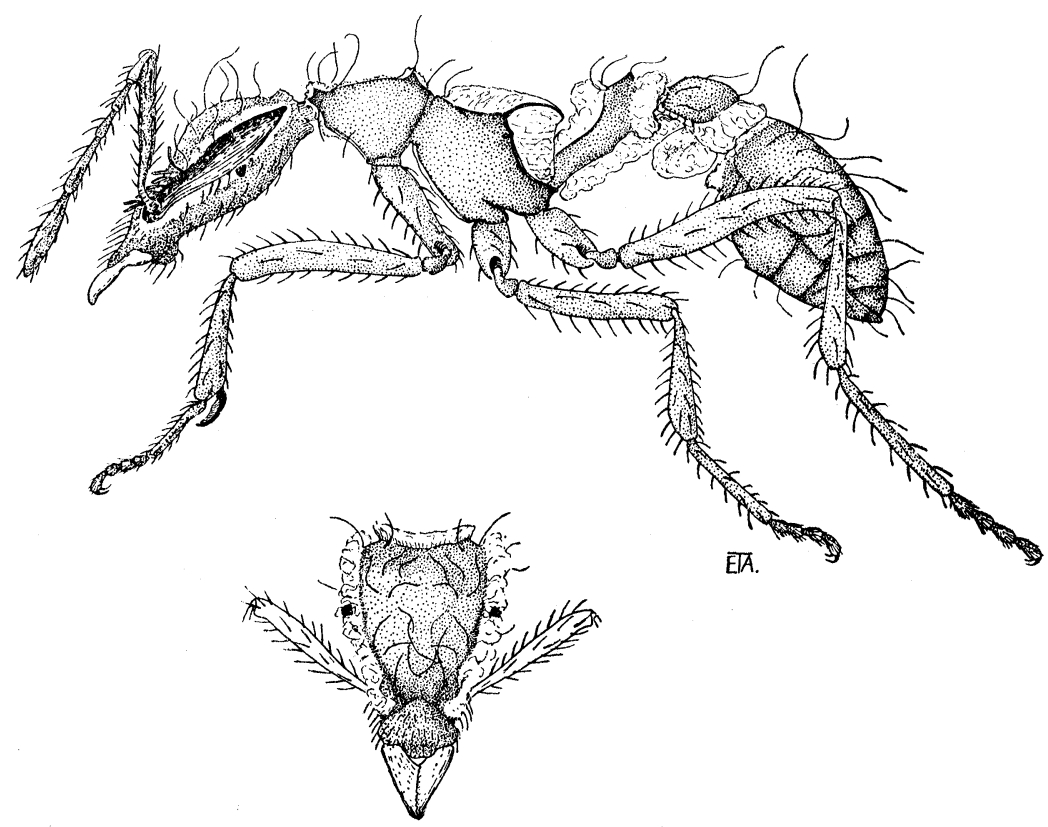

Fig. 1. Strumigenys (Tingimyrmex) mirabilis, new species, worker.

Strumigenys (Tingimyrmex) mirabilis, new species (Fig. 1).

Worker.-Length $2.25 \mathrm{~mm}$.

Head, excluding mandibles, nearly two times as long as broad and about twice as broad at occiput as in front, sides posterior to eyes nearly straight and parallel, in front of eyes convergent, then very feebly sinuate and slightly divergent to anterior border; occipital corners angulate, border shallowly emarginate; vertex rather strongly convex. Clypeus broadly convex, arcuate at anterior border. Mandibles a little more than 
half as long as head, slender, acuminate. Antennal scapes slender basally, somewhat thickened at apical half, attaining occipital corners; first funicular joint thicker and scarcely shorter than the second, which is a little more than three times as long as broad and subequal to the third, fourth joint two thirds as long as the terminal, which is subfusiform and pointed at tip. Eyes small, very convex, situated on lower margin of antennal fossa, well behind middle. Pronotum nearly flat, broadest in front, sides moderately arcuate, anterior angles with thick, blunt spines longer than broad, posterior angles with elevated, broad, lamellate triangular teeth, the bases of which continue as elevated side margins to the strongly sloping mesonotum. Epinotum slender, the base shorter than the declivity and rounding into it, strongly margined at sides, the margins prominently expanded and angulate between basal and declivous portions, nearly parallel on the declivity, nearly convergent anteriorly on the base, making that portion from above triangular in shape and less than twice as long as broad. Petiolar peduncle slender, longer than the node; node in profile with a rather concave dorsal surface, as long as the sloping anterior surface and much shorter than the posterior surface; from above transverse, prominently angulate at sides, subangulate in front, exposed posterior outline arcuate. Postpetiole nearly as broad as base of gaster and more than three times as broad as petiole, less than twice as broad as long, evenly convex above, anterior border straight, sides arcuate, posterior border in three subequal parts, the lateral lines feebly and the median distinctly emarginate. Legs long and rather slender.

Exposed areas smooth and shining, dorsal surface with sparse, exceedingly long and flexuous hairs, mingled on the head and thorax with shorter, coarser and strongly curved erect hairs; legs with stiff, moderately long, curved, semirecumbent hairs.

Pale brown, appendages lighter, gaster darker.

Type locality.-Huachi, Beni, Bolivia.

Cotype.-Cat. No. 29050 U. S. N. M.

Described from a series of workers found by the writer beneath a stone. 
In writing the description, a cleared specimen has been used to make out the outlines, which in parts are concealed by plates of thin semi-transparent chitin, the development of which is extreme in this species. This is not unlike yellowish mica with reticulate lines through it, and not only margins the clypeus, scrobes, occipital border of head and anterior border of pronotum, but occurs as high thin plates on the epinotal margins and the dorsal and ventral surface of petiole at middle and is acutally spread over the surface in places, especially on the clypeus and front of head (except the median portion of vertex).

These plates are chitinous in nature, as are the spongiform processes, and Dr. N. E. McIndoo, who kindly examined some specimens for me, writes as follows:

"In regard to the nature of the spongy material on the peduncle and other parts of a new species of ant from Bolivia, I believe that it is chitinous, and not a waxy secretion, for the following reasons. When an alcoholic peduncle had been cleared in xylene and mounted in balsam, and then observed under an oilimmersion lens, the porous or spongy material had the same shade of light yellow as that of the hairs and other chitinous parts; and the external wall of this material was continuous with the external wall of the chitinous integument. After the same peduncle had been treated with cold caustic potash for 18 hours, the spongy material was not destroyed. This is a sure test for the presence of chitinous structures. Considering the above and also that no pores are visible in the integument of this peduncle, it would appear that this material is formed when the hairs and chitinous integument are formed, and not at a later time." 

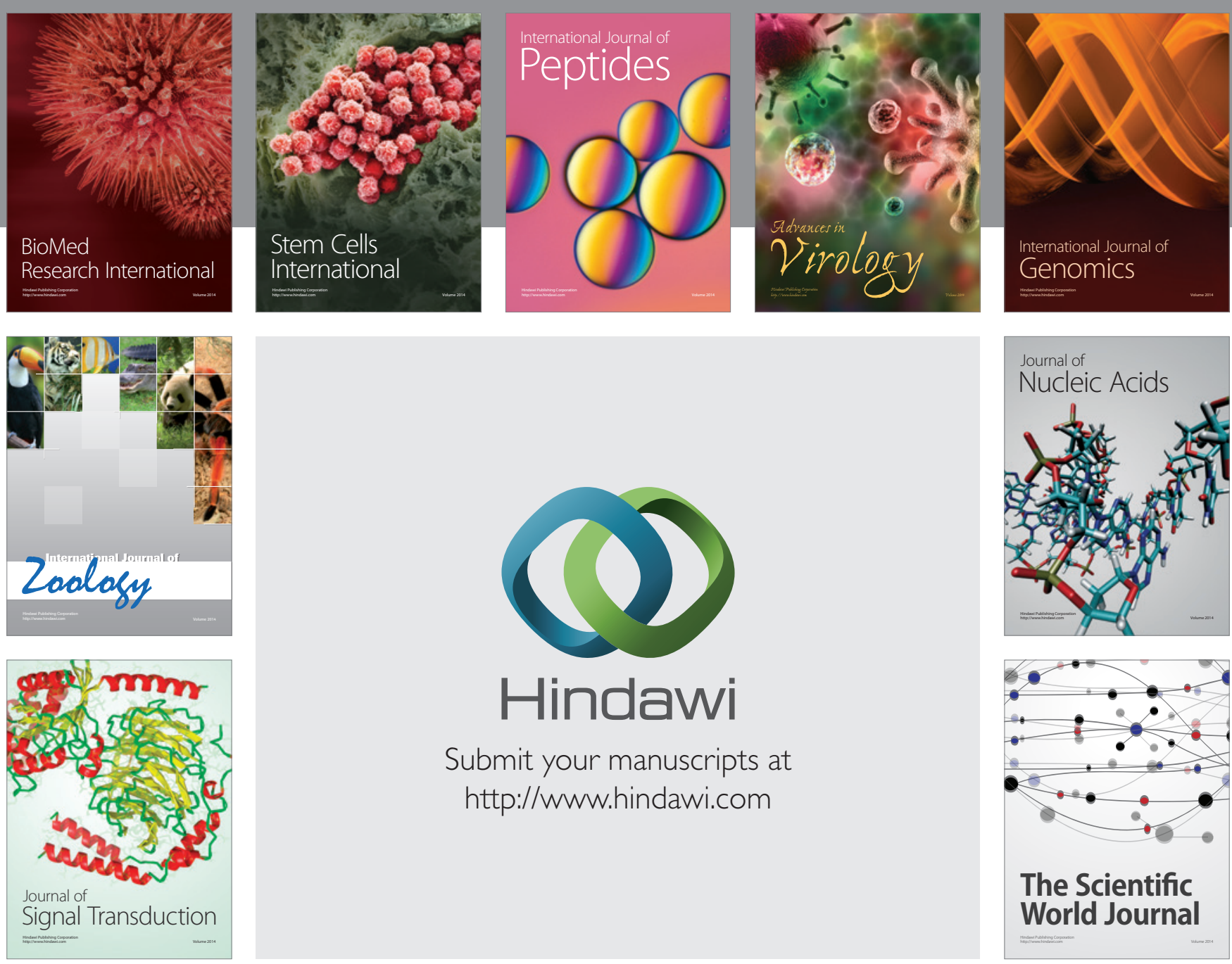

Submit your manuscripts at

http://www.hindawi.com
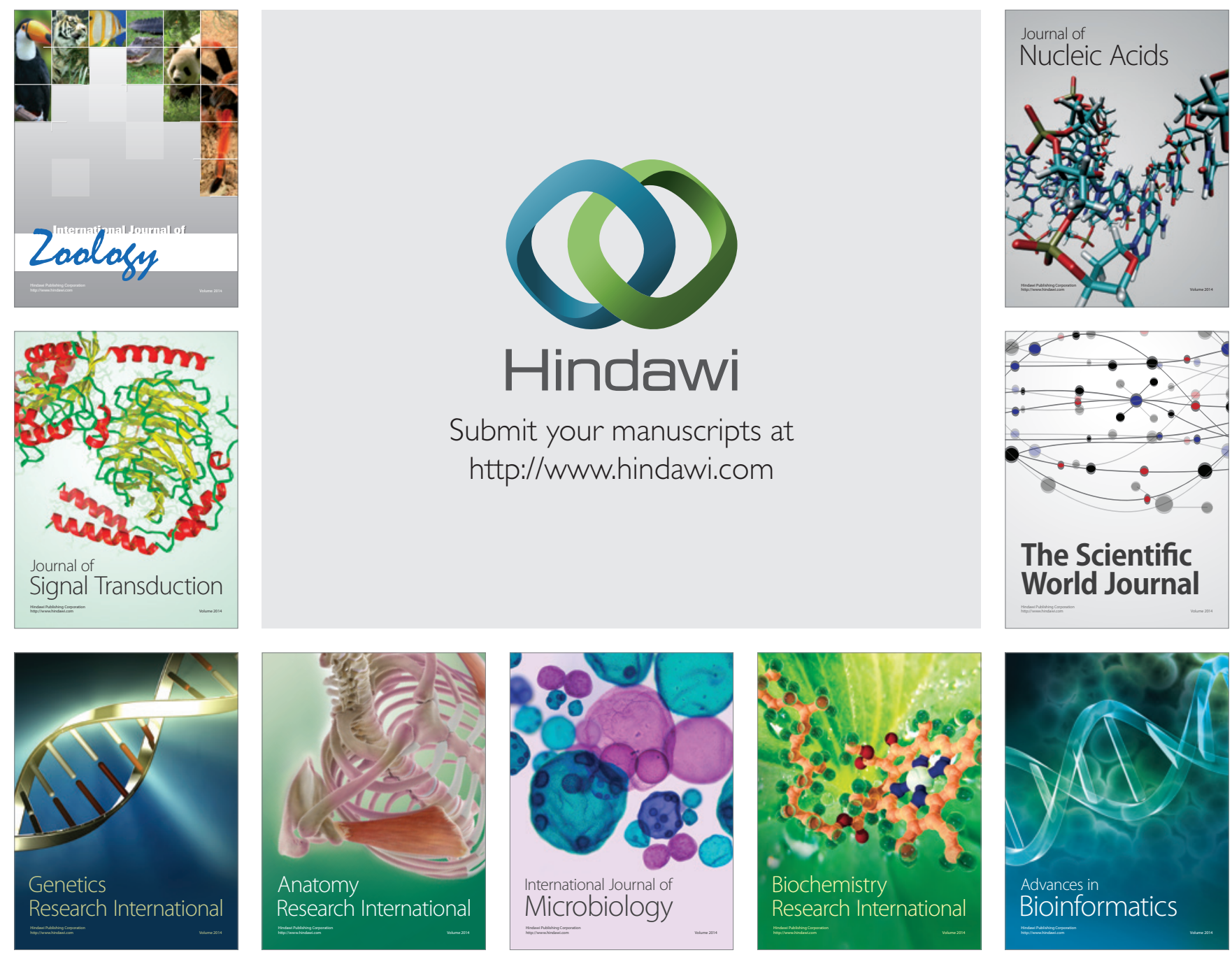

The Scientific World Journal
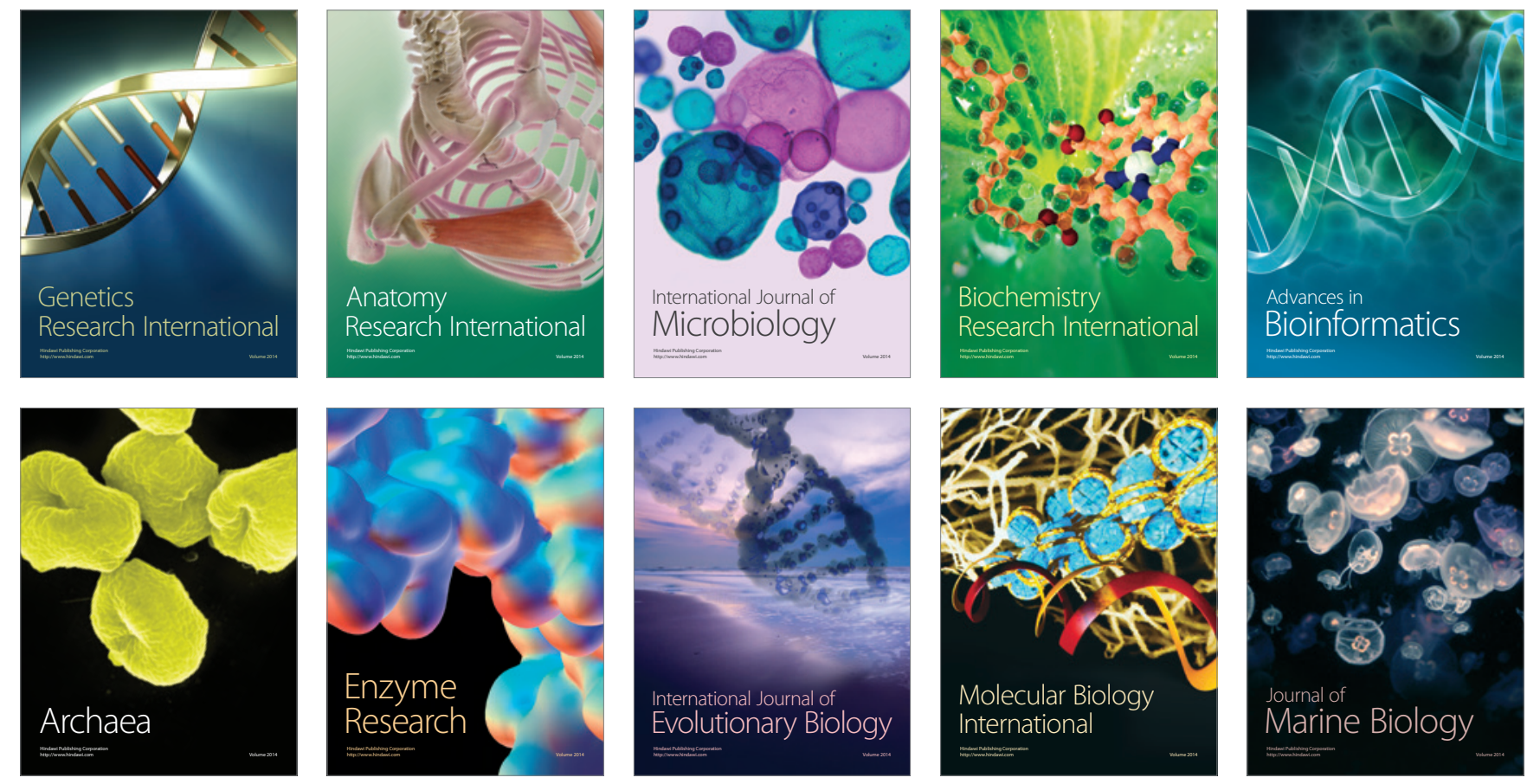